\title{
PROTEIN KINASES ACTIVATED BY cAMP IN THE GENITAL TRACT OF SPAYED MICE TREATED WITH OESTRADIOL-17 $\beta$
}

\author{
STEIN OVE DØSKELAND, STENER KVINNSLAND AND \\ PER MAGNE UELAND \\ Institute of Anatomy, University of Bergen, \\ Arstadveien 19, N-5000 Bergen, Norway
}

(Received 17th September 1974)

\begin{abstract}
Summary. The cAMP-dependent protein kinase (ATP:protein phosphotransferase, EG 2.7.1.37), has been studied in the vaginal epithelium, vaginal stroma, endometrium, and whole uterus of spayed mice treated with oestradiol-17 $\beta$, and in the vaginal epithelium and uterus of spayed mice. Two protein kinase isoenzymes (PK I and PK II) were found in whole uterus, endometrium, and vaginal stroma. Vaginal epithelium contained only one isoenzyme (PK II). Oestradiol treatment increased PK I relative to PK II in the uterus. The isoenzyme pattern in the vaginal epithelium was unaltered after such treatment. The total protein kinase activity was $70 \%$ higher in uterine extracts (cytosol) than in extracts from vaginal epithelium. Oestradiol treatment did not influence the total protein kinase activity in either tissue.
\end{abstract}

\section{INTRODUCTION}

Adenosine $3^{\prime}, 5^{\prime}$ cyclic monophosphate (cAMP)-dependent protein kinase (ATP:protein phosphotransferase, EC 2.7.1.37) is believed to be the major mediator of the cAMP effects in the cell (Langan, 1973). The importance of cAMP as a second messenger for polypeptide hormones and monoamines is widely accepted (Robison, 1970; Robison, Butcher \& Sutherland, 1971), and the cAMP system has also been implicated in the mediation of sex steroid effects in target organs (Szego, 1972; Singhal, 1973).

The aim of this work was to study cAMP-dependent protein kinase in different parts of the genital tract of spayed mice treated with oestradiol. The possible influence of oestradiol on the cAMP effector system, its effect on the concentration of protein kinase and the protein kinase isoenzyme pattern in target cells, was examined.

\section{MATERIALS AND METHODS}

Animals

Female virgin NMRI-mice, weighing 20 to $25 \mathrm{~g}$, were used. They were allowed free access to a standard pellet diet and water. 


\section{Chemicals}

The $\left[8-{ }^{3} \mathrm{H}\right] \mathrm{cAMP}(30 \mathrm{Ci} / \mathrm{mmol})$ and $\left[\gamma^{32} \mathrm{P}\right] \mathrm{ATP}$ (approx $16 \mathrm{Ci} / \mathrm{mmol}$ when delivered) were from The Radiochemical Centre, Amersham. The $\left[\gamma^{32} \mathrm{P}\right]$ ATP was used within 4 weeks of delivery. Whole calf thymus histone, cAMP, ATP, ethyleneglycol-bis- (amino-ethylether) $\mathrm{N}-\mathrm{N}^{\prime}$-tetra-acetic acid (EGTA) and oestradiol-17 $\beta$ were obtained from Sigma. Other chemicals were of analytical grade. Sucrose was from Koch-Light, other chemicals from Merck.

\section{Treatment of animals and preparation of cytosol}

One group of forty mice received oestradiol- $17 \beta(5 \mu \mathrm{g}$ in $0.025 \mathrm{ml}$ olive oil subcutaneously) $40 \mathrm{hr}$ and $16 \mathrm{hr}$ before autopsy. The control group of eighty mice received olive oil. Vaginal epithelium, vaginal stroma, endometrium, and whole uteri were collected from the oestradiol-treated mice; only vaginal epithelium and whole uteri were collected from control animals. All mice had been ovariectomized at least 1 week before autopsy. The mice were killed by cervical dislocation. The uterine horns and vaginae were rapidly removed and stripped of adhering connective tissue. The vaginal epithelium and endometrium were separated from stroma by gentle scraping with a scalpel blade. A smear of the specimen of vaginal epithelium so obtained was stained with Giemsa (Merck), examined microscopically and found to consist of epithelial cells and some keratin flakes. Histological scrutiny of the stroma stripped of the epithelium demonstrated that the scraping extended to the basement membrane, and that only a few scattered 'islands' of basal epithelium remained with the stroma.

After removal, the tissue specimens were dropped into liquid nitrogen and kept frozen. Immediately before homogenization, they were transferred to

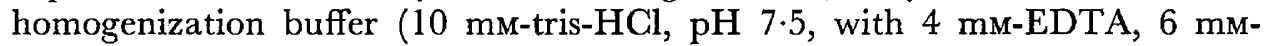
mercaptoethanol (ME) and $0.27 \mathrm{M}$-sucrose), finely minced with scissors, and homogenized by four strokes in a Thomas type $\mathrm{C}$ teflon-glass homogenizer with a pestle speed of $465 \mathrm{rev} / \mathrm{min}$. Cytosol was prepared from crude homogenate by spinning at $24,000 \mathrm{~g}$, removing the supernatant and spinning it again for $1 \mathrm{hr}$ at $100,000 \mathrm{~g}$ in the 460-rotor of a B-60 International Ultracentrifuge.

\section{Assay of protein kinase and estimation of tissue concentration of protein kinase}

Protein kinase activity was measured by a slight modification of the procedure described by Reimann, Walsh \& Krebs (1971). Protein kinase activity in tissue extracts (cytosol) was estimated in several dilutions of the cytosol preparation (desalted by passing through Sephadex G-25 columns equilibrated with Hepes buffer, $\mathrm{pH} 7 \cdot 0$ ). Protein kinase activity was plotted against the amount of cytosol protein, and the angle coefficient of the linear part of the plot taken as the protein kinase activity/unit cytosol protein. Linearity of protein kinase activity versus concentration ensured that protein kinase inhibitor did not influence the protein kinase assay (Døskeland \& Ueland, 1975).

Gel chromatography, ion-exchange chromatography, and sucrose density gradient centrifugation

Gel chromatography was performed on a $1.6 \times 65 \mathrm{~cm}$ column packed with 
Sepharose 4B (Pharmacia), and equilibrated with $10 \mathrm{~mm}$-tris-HCl buffer, $\mathrm{pH} 7 \cdot 5$, containing $4 \mathrm{~mm}-\mathrm{EDTA}$ and $6 \mathrm{~mm}-\mathrm{ME}$. The DEAE-cellulose chromatography was performed on a $0.9 \times 15 \mathrm{~cm}$ column packed with DE-52 (Whatman), and equilibrated with $10 \mathrm{~mm}$-tris-HCl buffer, $\mathrm{pH} 7 \cdot 5$, containing $4 \mathrm{~mm}$ EDTA and $6 \mathrm{~mm}-\mathrm{ME}$. Elution was with a linear gradient of 0 to $0.25 \mathrm{M}-\mathrm{KCl}$. Rate sedimentation was in a 5 to $20 \%$ (w/v) sucrose gradient, spun for $20 \mathrm{hr}$ at $40,000 \mathrm{rev} / \mathrm{min}$ in the 488 rotor of a B-60 International Ultracentrifuge. The sample was mixed with bovine serum albumin (BSA) before being layered on top of the gradient. The position of BSA in the gradient was determined by passing the gradient through a Gilford u.v. monitor.

\section{RESULTS}

Gel filtration and DEAE-cellulose chromatography of cytosol protein kinase

Cytosols were chromatographed on a Sepharose 4B column, and the fractions containing the main kinase and cAMP-binding activities were pooled and

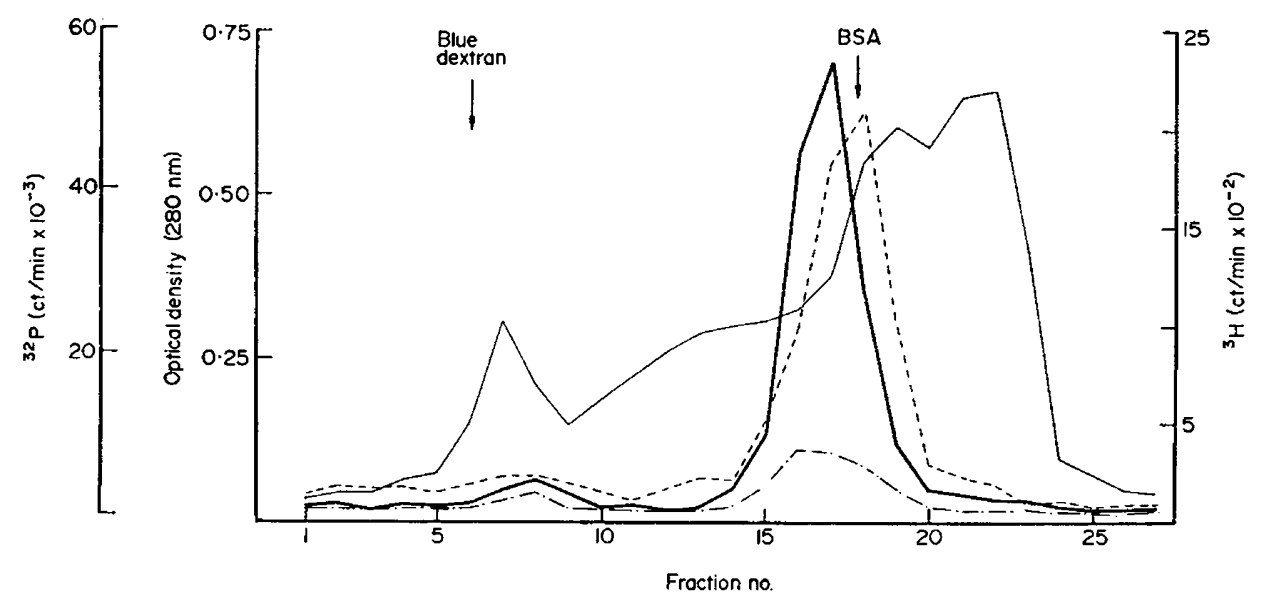

TExr-Frg. 1. Gel-chromatography of cytosols from the reproductive tissues of spayed mice; a representative experiment. $\longrightarrow$, Optical density, $280 \mathrm{~nm} ; \longrightarrow$, protein kinase activity measured in the presence of $4 \mu \mathrm{M}$-cAMP; -...-, activity without added cAMP; - - cAMP bound. The elution volumes of Blue dextran (Pharmacia) and BSA are indicated by arrows.

analysed by DEAE-cellulose chromatography. The elution profile on Sepharose $4 \mathrm{~B}$ was similar for cytosols from the different tissues investigated, and only one representative experiment is shown (Text-fig. 1). The first minor peak of kinase activity was eluted rapidly, its activity was modestly stimulated by cAMP (approx. twofold). The main peaks of kinase and cAMP-binding activities did not co-chromatograph completely, the cAMP binding lagging somewhat behind. Distinct tissue differences of protein kinase elution pattern were observed on DEAE-cellulose chromatography (Text-fig. 2). For vaginal epithelium, only one peak of protein kinase activity (PK II) emerged (Text-fig. 2a, b). This protein kinase was moderately (approx. fivefold) stimulated by cAMP.

Cyclic AMP activity was partly associated with this protein kinase activity 

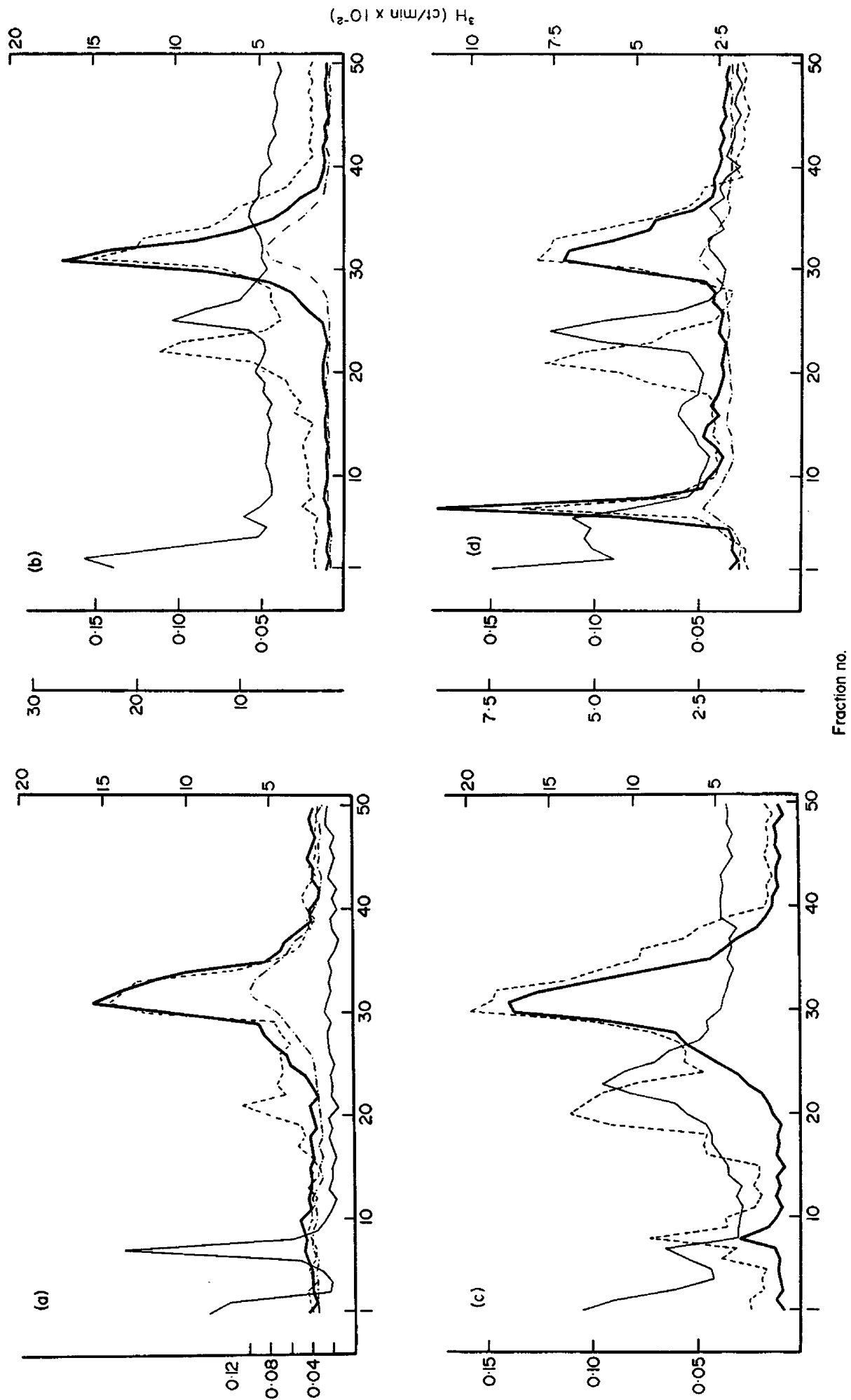

(wu O8Z) K!!suəp |0э!!do

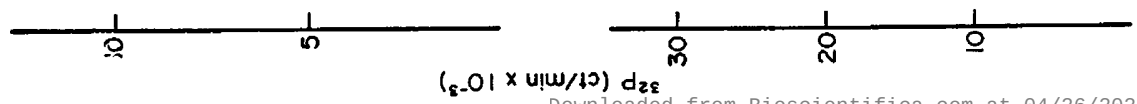




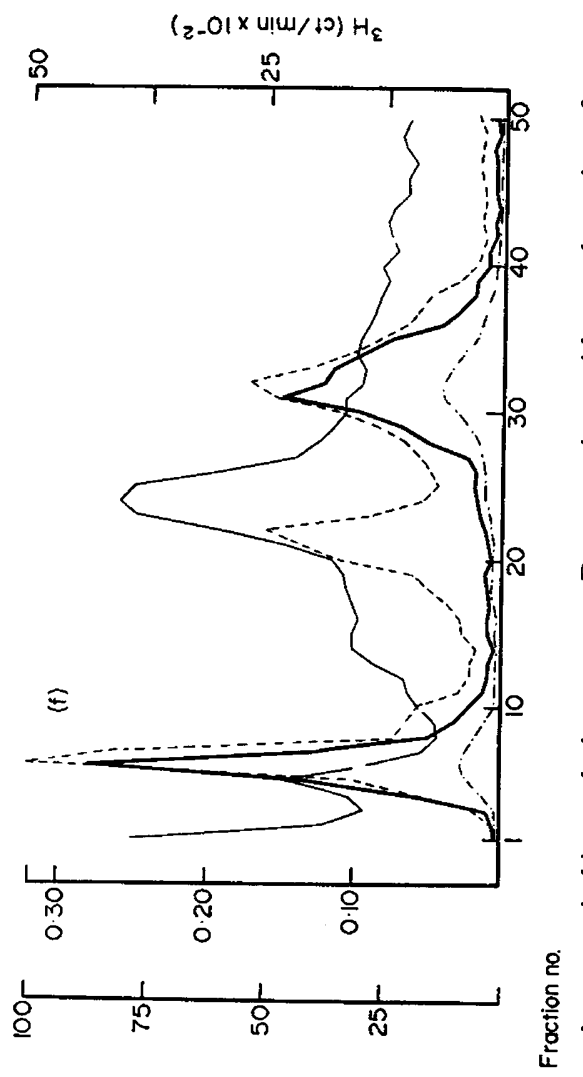

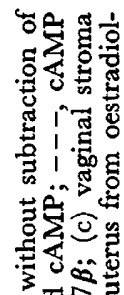

든

.

할

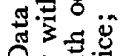

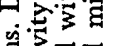

氖或

琼

. $\mathrm{i}$ i. 总

运实

उदु

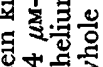

응

을잉

현

ก

월월

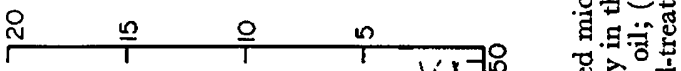

․․혛

究

पै

昰

뎐

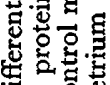

害

층 형

훙혀응

웅.

हू.

突

䒠可

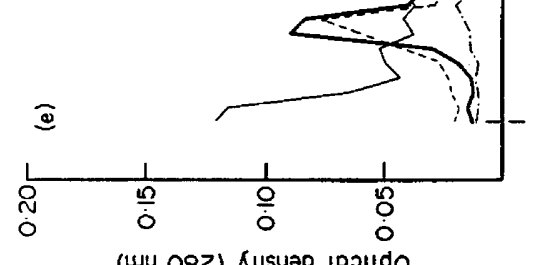

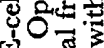

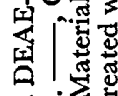

จ่ंฮี

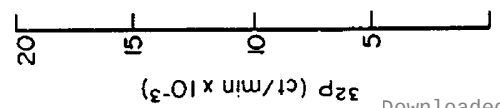



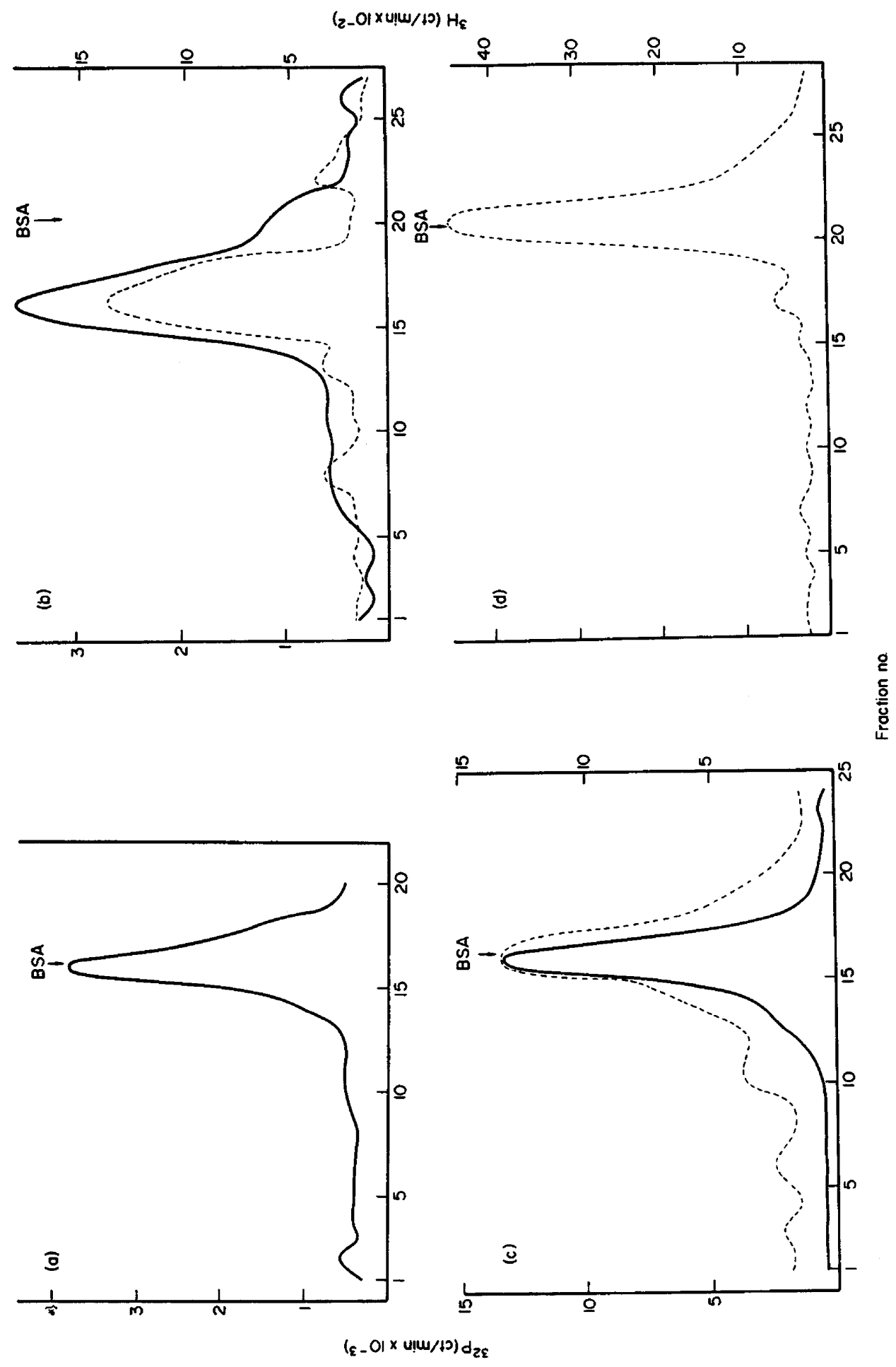
and partly emerged as a separate peak in front of the kinase activity. The vaginal stroma (Text-fig. 2c) also showed a small, but consistent peak of protein kinase activity (PK I) which was eluted at low ionic strength. It was highly (approx. 20-fold) stimulated by cAMP. In the endometrium (Text-fig. 2d) and uterus (Text-fig. 2e, f), PK I was more pronounced relative to PK II than it was in the vaginal stroma. Uteri stimulated with oestradiol (Text-fig. 2f) had more PK I relative to PK II than unstimulated uteri (Text-fig. 2e). Oestradiol did not alter the elution pattern for the vaginal epithelium (Textfig. 2a, b).

\section{Sucrose gradient centrifugation}

Protein kinase I (Text-fig. 3b) had a higher sedimentation coefficient (7.5S) than protein kinase II (Text-fig. 3a, c), which sedimented at 5S. The cAMP-binding material devoid of kinase activity, isolated by DEAE-cellulose chromatography, sedimented at approx. $4 \cdot 6 \mathrm{~S}$ (Text-fig. $3 \mathrm{~d}$ ).

\section{Tissue concentration of protein kinase}

The concentration of protein kinase in cytosols from the vaginal epithelium and uterus is shown in Text-fig. 4. The protein kinase concentration (given as

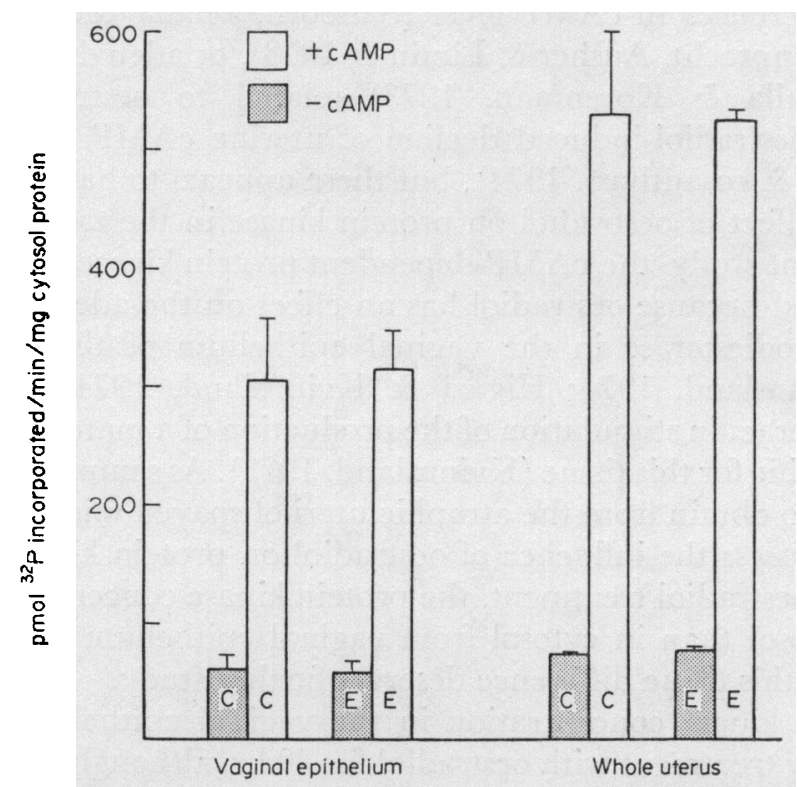

TEXT-FIG. 4. Mean cytosol protein kinase concentrations in vaginal epithelium and whole uterus of spayed mice treated with olive oil only (C) or with oestradiol-17 $\beta$ (E). There were three mice in each group; the S.E.M. is indicated by the vertical bars.

TExT-FIG. 3. Rate sedimentation in sucrose gradients of protein kinases of different tissues from spayed mice. Background counts were not subtracted. - , Protein kinase activity; - - , cAMP bound. (a) Protein kinase II in the vaginal epithelium of oestradiol-treated mice (the cAMP binding was not measured); (b) protein kinase I in whole uterus of oestradiol-treated mice; (c) protein kinase II, in whole uterus of oestradiol-treated mice; (d) free cAMP binding activity in whole uterus of mice treated with oestradiol-17 $\beta$. 
activity/mg cytosol protein but strictly, the concentration of the catalytic sub-unit of the protein kinase holoenzyme) was $70 \%$ higher in the uterus than in the vaginal epithelium. This tissue difference was not influenced by oestradiol. Statistical analysis (Wilcoxon two-sample test) showed the observed difference of protein kinase concentration between uterus and vagina to be highly significant $(P=0.0021)$. The protein kinase activity in the absence of cAMP (basal activity) was also significantly higher in uterus $(P=0.013)$, and not influenced by oestradiol.

\section{DISCUSSION}

Activation of the enzyme protein kinase, leading to phosphorylation of key protein substrates, has been considered the prime and, until now, the only well-established intracellular action of cAMP (Langan, 1973). The total protein kinase activity in a cell at a given moment would be expected to be governed primarily by the level of cAMP and the concentration of protein kinase.

The observed increase of the cAMP level in rat uteri after stimulation with oestradiol (Szego \& Davis, 1967; Dupont-Mairesse, Van Sande, Rooryck, Fastrez-Boute \& Galand, 1974) is relevant to the possible rôle of the cAMPprotein kinase system for the oestradiol effect. Other studies have failed to detect any differences in cAMP level (Sanborn, Bhalla \& Korenman, 1973; Zor, Koch, Lamprecht, Ausher \& Lindner, 1973), or adenylate cyclase activity (Sanborn, Bhalla \& Korenman, 1973) related to oestradiol stimulation. Recently, an oestradiol-induced decline of uterine cAMP level has been reported (Kuehl \& co-authors, 1974), but there appears to have been no investigation of the effect of oestradiol on protein kinase in the target tissues.

In the present study, the cAMP-dependent protein kinase in vaginal epithelium was studied because oestradiol has an effect on the adenylate cyclase and cAMP phosphodiesterase in the vaginal epithelium of the neonatal mouse (Åbro \& Kvinnsland, 1974; Higazi \& Kvinnsland, 1974). Oestradiol and cAMP also interact in stimulation of the production of a material with antigenic properties specific for this tissue (Kvinnsland, 1973). As samples of endometrium were difficult to obtain from the atrophic uteri of spayed mice, whole uteri had to be used to assess the influence of oestradiol on protein kinase in this tissue. Regardless of oestradiol treatment, the protein kinase concentration was higher in uterine cytosol than in cytosol from vaginal epithelium (Text-fig. 4). The significance of this tissue difference deserves further study.

The protein kinase concentration in the vaginal epithelium and uterus is not changed by treatment with oestradiol for $40 \mathrm{hr}$, although an intense protein synthesis in response to oestradiol occurs during this period (Hamilton, 1968; Billing, Barbiroli \& Smellie, 1969). In our study, protein kinase I had a very low activity in the absence of CAMP; it was four times more cAMP-dependent than PK II. Provided the conditions in vitro reflect those in the cell, one would expect the PK I to be suitable for an 'on-off phosphorylation', whereas PK II, with a higher basal activity, would be more suited for phosphorylations occurring continuously in the cell. When uterine cytosol was analysed by DEAEcellulose chromatography, it appeared that oestradiol increased the concen- 
tration of the highly cAMP-dependent PK I relative to the moderately cAMPdependent PK II (Text-fig. 2e,f). This oestradiol-induced change in the uterine isoenzyme pattern may give an altered pattern of protein phosphorylation in stimulated compared to unstimulated uteri, even if the cAMP level is the same. Oestradiol did not change the isoenzyme pattern in the vaginal epithelium, which only contained PK II (Text-fig. 2a, b).

On DEAE-cellulose chromatography, cAMP-binding activity devoid of kinase activity was found in all the tissues analysed (Text-fig. 2). The cAMPbinding material was partly separated from kinase activity by Sepharose 4B chromatography (Text-fig. 1), and by sucrose gradient centrifugation (unpublished results), indicating that the free cAMP-binding material is not an artefact introduced by DEAE-cellulose (Gill \& Garren, 1970) but is already present in cytosol.

\section{AGKNOWLEDGMENTS}

This investigation was supported by grants from the Norwegian Research Council for Science and the Humanities and from the Norwegian Cancer Society (Landsforeningen mot Kreft).

\section{REFERENGES}

Åro, A. \& Kvinnsland, S. (1974) Adenylate cyclase in an estradiol sensitive tissue: a cytochemical study. Histochemistry, 42, 333-344.

Billing, R. J., Barbiroli, B. \& Smellie, R. M. S. (1969) The mode of action of estradiol. II. The synthesis of RNA. Biochim. biophys. Acta, 190, 60-65.

Døskeland, S. O. \& UeLand, P. M. (1975) Cyclic 3',5'-AMP-dependent protein kinase. Its sensitivity towards acid-precipitation and ammonium-sulphate-fractionation. Int. F. Biochem. (in press).

Dupont-Mairesse, N., Van Sande, J., Rooryck, J., Fastrez-Boute, A. \& Galand, P. (1974) Mechanism of estrogen action-independence of several responses of the rat uterus from the early increase in adenosine 3',5'-cyclic monophosphate. F. Steroid Biochem. 5, 173-177.

GiLl, G. N. \& GARREN, L. D. (1970) A cyclic 3',5'-adenosine monophosphate-dependent protein kinase from the adrenal cortex: comparison with a cyclic AMP binding protein. Biochem. biophys. Res. Commun. 39, 335-343.

Hamilton, T. M. (1968) Gontrol by estrogen of genetic transcription and translation. Science, N.Y. $161,649-661$.

Higazi, M.G. \& KvinnsLand, S. (1974) Estradiol-17 $\beta$ : its influence on cyclic $3^{\prime}, 5^{\prime}$-adenosine monophosphate phosphodiesterase and $5^{\prime}$-nucleotidase in the cervicovaginal epithelium of neonatal mice. 7. Reprod. Fert. 36, 135-139.

Kuehl, F. A., Ham, E. A., Zanietti, M. E., SAndford, G. H., Nicol, S. E. \& Goldberg, N. D. (1974) Estrogen-related increases in uterine guanosine $3^{\prime}, 5^{\prime}$-cyclic monophosphate levels. Proc. natn. Acad. Sci. U.S.A. 71, 1866-1870.

KvinnsLand, S. (1973) Estradiol-17 $\beta$, cyclic AMP and prostaglandins: in vivo and in vitro studies on the cervicovaginal epithelium from neonatal mice. Life Sci. 12, 373-384.

Langan, T. A. (1973) Protein kinases and protein kinase substrates. Adv. cyclic Nucleotide Res. 3, 99-153.

Reimann, E. M., Walsh, D. A. \& Krebs, E. G. (1971) Purification and properties of rabbit skeletal muscle adenosine 3',5'-monophosphate-dependent protein kinases. F. biol. Chem. 246, 1986-1995.

Robison, G. A. (1970) Cyclic AMP as a second messenger. F. Reprod. Fert., Suppl. 10, 55-74.

Robison, G. A., Butcher, R. W. \& Sutherland, E. W. (1971) Cyclic AMP and hormone action. In Cyclic AMP, Chap. 2, pp. 17-47. Eds. G. A. Robison, R. W. Butcher \& E. W. Sutherland. Academic Press, New York and London.

Sanborn, B. M., Bhalla, R. G. \& Korenman, S. G. (1973) Use of a modified radioligand assay to measure the effect of estradiol on uterine adenosine $3^{\prime}, 5^{\prime}$-cyclic monophosphate. Endocrinology, 92, 494-499.

Singhal, R. L. (1973) Cyclic AMP and estrogenic stimulation of uterine metabolism. Adv. Pharmac. Chemother. 11, 1-54. 
Szego, G. M. (1972) The role of cyclic AMP in lysosome mobilization and their nucleotropic translocation in steroid hormonal target cells. Adv. cyclic Nucleotide Res. 1, 541-564.

Szego, C. M. \& Davis, J. S. (1967) Adenosine 3',5'-monophosphate in rat uterus: acute elevation by estrogen. Proc. natn. Acad. Sci. U.S.A. 58, 1711-1718.

Zor, U., Koch, Y., Lamprecht, S. A., Ausher, J. \& Lindner, H. R. (1973) Mechanism of oestradiol action on the rat uterus: independence of cyclic AMP, prostaglandin $E_{2}$ and adrenergic mediation. 7. Endocr. 58, 525-533. 